\title{
Polycyclic aromatic compounds as anticancer agents: Evaluation of synthesis and in vitro cytotoxicity
}

\author{
DEBASISH BANDYOPADHYAY ${ }^{1}$, JOSE C. GRANADOS ${ }^{2}$, JOHN D. SHORT $^{2,3}$ and BIMAL K. BANIK ${ }^{1}$ \\ ${ }^{1}$ Department of Chemistry, The University of Texas-Pan American, Edinburg, TX 78539; ${ }^{2}$ University of Texas Health \\ Science Center at San Antonio-Regional Academic Health Center, Medical Research Division, Edinburg, TX 78541; \\ ${ }^{3}$ Department of Pharmacology, University of Texas Health Science Center at San Antonio, San Antonio, TX 78229, USA
}

Received April 15, 2011; Accepted June 20, 2011

DOI: $10.3892 / \mathrm{ol} .2011 .436$

\begin{abstract}
Polycyclic aromatic hydrocarbons (PAHs) are considered to be significant environmental carcinogens. Additionally, various planar ring systems are capable of intercalating with DNA, leading to a number of drugs that possess chemotherapeutic activity. In this study, three new polyaromatic compounds with a side chain were synthesized, and spectroscopic as well as elemental analyses were performed. The addition of the long chains to either chrysene or pyrene caused a red-shift in the spectral emission when compared to the corresponding polycyclic aromatic hydrocarbons itself. Furthermore, the cytotoxicity of the three novel polyaromatic compounds was evaluated in vitro in a panel of cultured mammalian cell lines. The pyrenyl ether demonstrated better cytotoxicity compared to cisplatin against colon (HT-29) as well as cervical (HeLa) cancer cell lines. In conclusion, three new compounds were synthesized and investigated in this study. This novel method is likely to play a role in other areas of research.
\end{abstract}

\section{Introduction}

Polycyclic aromatic hydrocarbons (PAHs) are widely distributed in nature and are considered to be significant environmental carcinogens. Although they are generally formed at high temperatures, PAHs should be considered as biologically inactive. The major sources of these hydrocarbons include, but are not limited to, power plants, gasoline, coal tar and diesel engines. PAHs are soluble in lipid, can be metabolized and

Correspondence to: Dr John D. Short, University of Texas Health Science Center at San Antonio-Regional Academic Health Center, Medical Research Division, 1214 West Schunior Street, Edinburg, TX 78541, USA

E-mail: shortj@uthscsa.edu

Dr Bimal K. Banik, Department of Chemistry, The University of Texas-Pan American, 1201 West University Drive, Edinburg, Texas 78539, USA

E-mail: banik@utpa.edu

Key words: polyaromatic, antitumor, cytotoxicity, liver cancer, emission spectrum are capable of interacting with cellular components, such as protein and nucleic acid. The metabolic activation of PAH is responsible for their carcinogenic properties. Since PAHs require metabolic activation, they are considered to be indirect acting carcinogens (1). On the other hand, DNA intercalators, an important class of antitumoral DNA binders, are characterized by the insertion of planar aromatic or heteroaromatic rings between DNA base pairs (2,3), as in the case of anthracyclines, acridines and ellipticines $(4,5)$, which are thought to poison topoisomerases I and II (6). Various factors are involved in the stabilization of the drug-DNA complex, of which hydrogen bonding and $\pi$-stacking are the most important. Moreover, PAHs constitute an important class for the design of new chemotherapeutic DNA intercalators $(7,8)$.

PAH-containing anticancer compounds were first reported to be present in either the anthracene (8-11) or the pyrene ring systems (1,12-14). DNA-binding molecules are considered to be an important class of drugs in anticancer therapy (15). Although it is well-established that DNA binding is not sufficient to confer cytotoxic activities, interaction with DNA is often considered a necessary criterion for maintaining a cytotoxic effect. The antitumoral anthracyclines daunorubicin and doxorubicin and the synthetic anthracene-9,10-dione mitoxantrone are potent agents in clinical use at present, with broad application in the treatment of several leukemias and lymphomas as well as in combination chemotherapy of solid tumors $(16,17)$.

It is well-known that cancer is the leading cause of death in people under the age of 85 in the United States, and mortality from this disease appears to be on the increase (18). Therefore, it is imperative to develop new compounds and strategies to decrease the incidence and mortality of cancer. As a part of our ongoing research $(7,19-29)$ to synthesize new PAH-bearing anticancer agents, we report the synthesis and in vitro cytotoxic evaluation of certain new PAH compounds (Fig. 1).

\section{Materials and methods}

Materials. The following materials were obtained for the study: PAH (chrysene and pyrene), bismuth nitrate pentahydrate, montmorillonite KSF clay, indium, ammonium chloride, isobutyl chloroformate, 1.0 M borane in tetrahydrofuran, reagent grade solvents (Aldrich Chemical Co., St. Louis, MO, USA), dimethylsulfoxide (DMSO; Sigma-Aldrich Corp., 
St. Louis, MO, USA), phosphate-buffered saline (PBS), Dulbecco's modified Eagle's medium (DMEM) (Invitrogen, Carlsbad, CA, USA), fetal bovine serum (FBS; Invitrogen), McCoy's media (Invitrogen) and doxorubicin (Fisher Scientific, Pittsburgh, PA, USA).

Synthesis of the compounds 1, 2 and 3. Melting points were determined in a Fisher Scientific electrochemical Mel-Temp* manual melting point apparatus (Model 1001) equipped with a $300^{\circ} \mathrm{C}$ thermometer. Elemental analyses $(\mathrm{C}, \mathrm{H}, \mathrm{N})$ were conducted using the Perkin-Elmer 2400 series II elemental analyzer. Their results were found to be in agreement $( \pm 0.2 \%)$ with the calculated values for $\mathrm{C}, \mathrm{H}, \mathrm{N}$. FT-IR spectra were registered on a Bruker IFS 55 Equinox FT-IR spectrophotometer as $\mathrm{KBr}$ discs. ${ }^{1} \mathrm{H}-\mathrm{NMR}(300 \mathrm{MHz})$ and ${ }^{13} \mathrm{C}-\mathrm{NMR}(75.4 \mathrm{MHz})$ spectra were obtained at room temperature with JEOL Eclipse300 equipment using TMS as an internal standard and $\mathrm{CDCl}_{3}$ as a solvent. Analytical grade chemicals (Sigma-Aldrich Corp.) were used throughout the study. Deionized water was used for the preparation of all aqueous solutions.

PAH nitration. Chrysene or pyrene $(1 \mathrm{mmol})$ and montmorillonite KSF clay (500 mg; Aldrich Chemical Co.) were added to a suspension of bismuth nitrate pentahydrate $(1 \mathrm{mmol})$ in anhydrous dichloromethane $(10 \mathrm{ml})$. The solvent was then evaporated under reduced pressure and the reaction mixture was irradiated in a kitchen microwave for $6 \mathrm{~min}(2 \times 3 \mathrm{~min})$. After every $2 \mathrm{~min}$ the reaction was monitored by TLC. After completion of the reaction, the reaction mixture was washed with dichloromethane $(3 \times 5 \mathrm{ml})$ and the solvent was evaporated by reduced pressure distillation. The pure product was isolated by crystallization from a dichloromethane/hexanes mixture in excellent yield (>90\%).

Reduction of the nitrated PAH to the corresponding amine. The nitrated PAH (1 mmol) and indium $(570 \mathrm{mg}), 2.5 \mathrm{ml}$ ethanol and $2.5 \mathrm{ml} 20 \%$ aqueous ammonium chloride solution were refluxed vigorously for $24 \mathrm{~h}$ (monitored by TLC). After completion of the reaction, the mixture was filtered through a Büchner funnel and the filtrate was extracted with dichloromethane $(2 \times 3 \mathrm{ml})$. The dichloromethane layer was washed with brine and water successively and dried over anhydrous sodium sulfate. The pure amine was isolated by crystallization from a dichloromethane/hexanes mixture in excellent yield $(>80 \%)$.

Coupling of the polyaromatic amines with isobutyl chloroformate. The polyaromatic amine $(1 \mathrm{mmol})$ was stirred with triethylamine $(3 \mathrm{mmol})$ in anhydrous dichloromethane $(5 \mathrm{ml})$ at a temperature of -5 to $0^{\circ} \mathrm{C},(1.8 \mathrm{mmol}$ in $2 \mathrm{ml}$ anhydrous dichloromethane) was then added dropwise. Following the addition of Isobutyl chloroformate, the mixture was agitated for $24 \mathrm{~h}$ (monitored by TLC). After completion of the reaction, the mixture was washed with a saturated solution of sodium bicarbonate, brine and water successively. The pure product was isolated after column chromatography over silica gel (>70\% yield).

Reduction of 2 to 3 . Compound 2 (1 mmol) was refluxed with $6 \mathrm{ml}$ of $1.0 \mathrm{M}$ borane/tetrahydrofuran solution for $36 \mathrm{~h}$. Then, $5 \mathrm{ml}$ of $4 \%$ hydrochloric acid solution was added and the mixture was again refluxed for another $24 \mathrm{~h}$. After completion of the reaction, the $\mathrm{pH}$ of the solution was maintained at $\sim 7.0$ by $10 \%$ aqueous sodium hydroxide solution and the mixture was

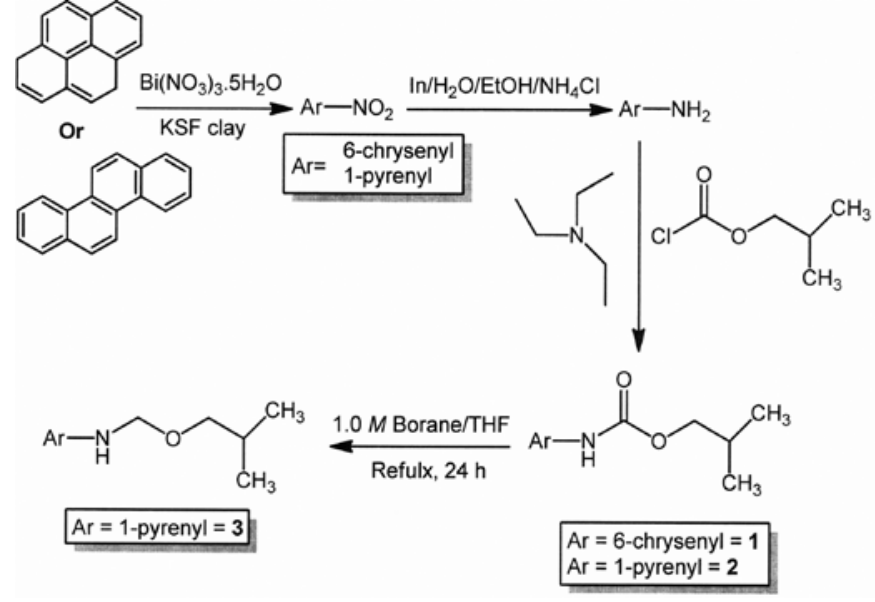

Figure 1. Synthesis of the compounds 1, 2 and 3.

extracted with ethyl acetate $(3 \times 3 \mathrm{ml})$. The organic layer was washed with brine and water successively. The pure product (compound 3) was isolated after column chromatography over silica gel (78\% yield).

Isobutyl chrysen-6-ylcarbamate (compound 1). $\mathrm{mp} 181^{\circ} \mathrm{C}$; IR (KBr disc, $\left.\mathrm{cm}^{-1}\right): 3278,3269,1695,1535,1239,1165,972$, 829; ${ }^{1} \mathrm{H}-\mathrm{NMR} \delta\left(\mathrm{CDCl}_{3}, \mathrm{ppm}\right): 0.99$ (m, 6H, methyl), $2.00(\mathrm{~m}$, 1H, methine), 3.98 (m, 2H, methylene), 7.19 (broad s, NH), 7.89-8.09 (m, 11H, Ar-H); ${ }^{13} \mathrm{C}-\mathrm{NMR}\left(\mathrm{CDCl}_{3}, \mathrm{ppm}\right) \delta: 19.56$ (2C), 28.40, 70.76, 111.98, 119.78, 122.43, 122.47, 126.54, 126.87, 126.89, 126.94, 126.98, 127.07, 127.98, 128.65, 128.69, 129.87, 129.98, 130.08, 131.86, 131.99, 156.51. Anal. Calcd. for $\mathrm{C}_{23} \mathrm{H}_{21} \mathrm{NO}_{2}$ : C, 80.44; H, 6.16; N, 4.08. Experimental: C, 80.30; H, 6.10; N, 3.91.

Isobutyl pyren-4-ylcarbamate (compound 2). mp $146-148^{\circ} \mathrm{C}$; IR (KBr disc, $\left.\mathrm{cm}^{-1}\right): 3282,3276,1696,1560,1527,1241,1112$, 971, 865; ${ }^{1} \mathrm{H}-\mathrm{NMR} \delta\left(\mathrm{CDCl}_{3}, \mathrm{ppm}\right): 1.01$ (m, 6H, methyl), 2.03 ( $\mathrm{m}, 1 \mathrm{H}$, methine), 4.06 (d, 2H, $J=6.49 \mathrm{~Hz}$, methylene), 7.21 (broad s, NH), 7.98-8.14 (m, 9H, Ar-H); ${ }^{13} \mathrm{C}-\mathrm{NMR}$ (CDCl3, ppm) \&: 19.23 (2C), 28.14, 71.89, 120.12, 124.87, 124.97(2C), 125.23 (2C), 125.35, 125.42 (2C), 126.21, 126.66, 127.39, 127.88, 130.70, 130.92, 131.49, 155.11. Anal. Calcd. for $\mathrm{C}_{21} \mathrm{H}_{19} \mathrm{NO}_{2}$ : C, 79.47; H, 6.03; N, 4.41. Experimental: C, 79.31; H, 5.91; N, 4.22.

N-(isobutoxymethyl)pyren-4-amine (compound 3). mp 76-78 ${ }^{\circ}$; IR ( $\mathrm{KBr}$ disc, $\left.\mathrm{cm}^{-1}\right): 2692,2669,2643,2358,1600$, 1514, 1282, 827; ${ }^{1} \mathrm{H}-\mathrm{NMR} \delta\left(\mathrm{CDCl}_{3}, \mathrm{ppm}\right): 0.94(\mathrm{~m}, 6 \mathrm{H}$, methyl), 2.08 (m, 1H, methine), 3.01 ( $\mathrm{m}, 2 \mathrm{H}$, methylene), 3.30 (m, 2H, methylene), 4.71 (broad s, NH), 7.31-8.06 (m, 9H, Ar-H); ${ }^{13} \mathrm{C}-\mathrm{NMR} \delta\left(\mathrm{CDCl}_{3}, \mathrm{ppm}\right): 21.88,28.17,31.24,108.27$, $116.53,119.44,122.45,123.03,123.24,123.36,123.87,124.21$, 125.71, 125.84, 126.01, 126.36, 126.54, 126.76, 127.12, 127.93, 143.59. Anal. Calcd. for $\mathrm{C}_{21} \mathrm{H}_{21} \mathrm{NO}$ : C, 83.13; H, 6.98; N, 4.62. Experimental: C, 82.89; H, 6.61; N, 4.51.

Spectral analyses of the compounds 1,2 and 3. Compounds 1, 2 and 3 were dissolved in DMSO at a concentration of $20 \mathrm{mM}$. For spectral analyses, compounds were then diluted to $50 \mu \mathrm{M}$ 


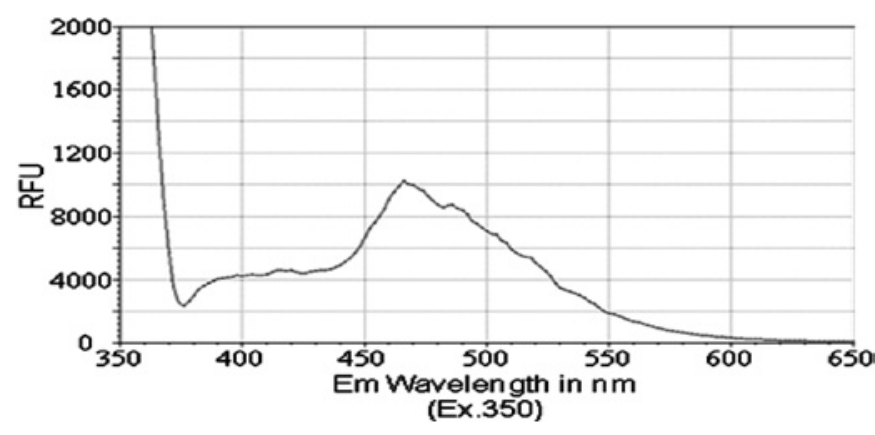

Figure 2. Emission spectrum of the compound 2 [compound $(50 \mu \mathrm{M})$ was diluted in PBS and excited at a wavelength of $350 \mathrm{nM}$ ].

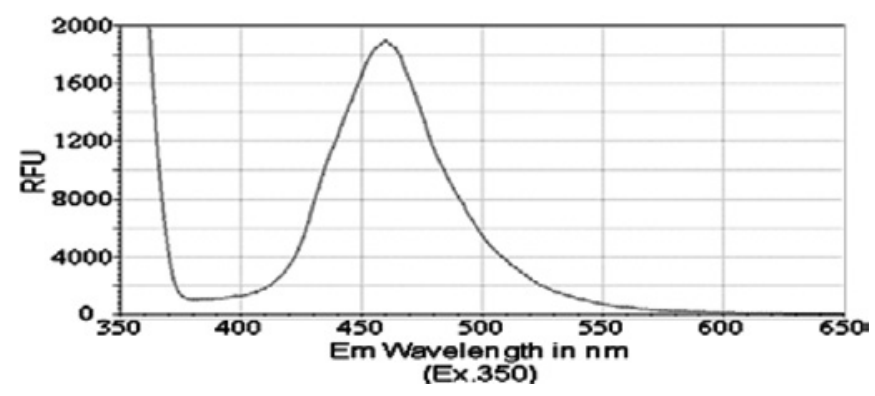

Figure 3. Emission spectrum of the compound 3 [compound $(50 \mu \mathrm{M})$ was diluted in PBS and excited at a wavelength of $350 \mathrm{nM}$ ].

in either DMSO or PBS. The absorbance of each compound, dissolved in either DMSO or PBS, was then analyzed between the wavelengths of 350-700 nM using a SpextraMaxM5 plate reader (Molecular Devices, Sunnyvale, CA, USA). In addition, diluted compounds were excited with light at a wavelength of $350 \mathrm{nM}$, and the subsequent light emission was analyzed between the wavelengths of 350-700 $\mathrm{nM}$ using a SpextraMaxM5 plate reader.

Mammalian cell culture. HepG2, Hepa1-6, NIH3T3 and HeLa cells were cultured in DMEM (Invitrogen) containing 10\% FBS (Invitrogen), Caco-2 cells were cultured in DMEM containing 20\% FBS and HT-29 cells were cultured in McCoy's media (Invitrogen) containing 10\% FBS. The cell lines were purchased from American Type Culture Collection (ATCC; Manassas, VA, USA) and incubated at $37^{\circ} \mathrm{C}$ with $5 \% \mathrm{CO}_{2}$.

Mammalian cell viability assay. Cells were plated onto a 96-well dish (5,000 cells/well) and incubated overnight at $37^{\circ} \mathrm{C}$. The following day, cells were treated with increasing dosages (3-100 $\mu \mathrm{M})$ of each compound, which had been dissolved in DMSO. The DMSO concentration of treatments was limited to $0.5 \%$, and cells were treated with DMSO alone $(0.5 \%)$ or $10 \mu \mathrm{M}$ doxorubicin as negative and positive controls for cytotoxicity, respectively. After $48 \mathrm{~h}$, cells were fixed and cell viability was analyzed using the Sulforhodamine B colorimetric assay as previously described (30). Absorbance of SRB was measured utilizing a SpextraMaxM5 plate reader and absorbance values were normalized to non-treated cells. The normalized cell viability with increasing drug doses was plotted on a four-parameter logistical curve, and the $\mathrm{IC}_{50}$ of each compound in each cell line was calculated using

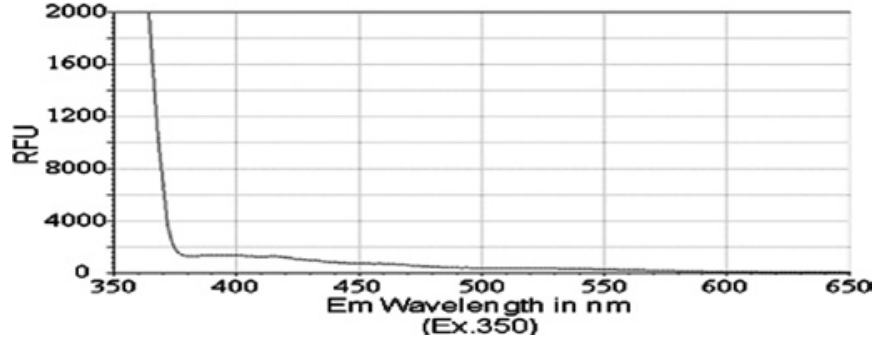

Figure 4. Emission spectrum of the compound 1 [compound $(50 \mu \mathrm{M})$ was diluted in PBS and excited at a wavelength of $350 \mathrm{nM}]$.

SigmaPlot software (Systat Software, Inc., Chicago, IL, USA). Each compound was synthesized in two independent reactions and used in cell viability assays to generate dose-response curves. The mean $\mathrm{IC}_{50}$ (in $\mu \mathrm{M}$ ), with the corresponding standard deviation of the two independent synthesis reactions, was then calculated.

Subcellular localization. Cells (7,200 cells/well) were plated onto Nunc Lab-TekII 8-chamber slides (Fisher Scientific) and incubated overnight at $37^{\circ} \mathrm{C}$. The following day, cells were treated with compound $(50 \mu \mathrm{M})$ for $4 \mathrm{~h}$. After treatment, cells were fixed with PBS containing $4 \%$ formaldehyde for $25 \mathrm{~min}$ at room temperature. Then, they were permeabilized using PBS containing $0.2 \%$ Triton-X-100 for $5 \mathrm{~min}$ at room temperature and mounted using VectaShield mounting medium containing DAPI (Fisher Scientific). The cells were visualized using a Zeiss AxioImager.Z1 epifluorescent microscope (Carl Zeiss Microimaging, LLC, Thornwood, NY, USA) with EGFP (Excitation 470/40; Emission 525/50) and DAPI filters, and images were acquired using AxioVision Rel. 4.6 software (Zeiss).

\section{Results and Discussion}

Spectral emission of the compounds 1, 2 and 3. Previous reports have identified that the peak emission wavelength of pyrene is less than $400 \mathrm{nM}$, with a shoulder for that emission peak at approximately $420 \mathrm{nM}(31,32)$. Similarly, chrysene was previously shown to exhibit a peak emission wavelength of less than $400 \mathrm{nM}$, with a shoulder for its emission peak at approximately $425 \mathrm{nM}$ (33). Therefore, we aimed to determine whether PAH derivatives 1-3 would have an impact on the absorption and spectral emission patterns of these molecules. Although no significant absorbance was detected for compounds in this study, i.e., compounds 1,2 and 3 , at wavelengths between 350 and $650 \mathrm{nM}$, we detected a fluorescence emission spectrum for each of the PAH derivatives. The peak emission wavelength for both isobutyl pyren-4-ylcarbamate (compound 2) and $\mathrm{N}$-(isobutoxymethyl)pyren-4-amine (compound 3) occurred between 460 and $470 \mathrm{nM}$ (Figs. 2 and 3). However, isobutyl chrysen-6-ylcarbamate (compound 1) exhibited a much smaller emission spectra (Fig. 4), with shoulders for its peak at 420 and $525 \mathrm{nM}$, when compared to compounds 2 and 3 (ig. 4 vs. Figs. 1 and 2). The limited fluorescence of this compound was possibly due to its crystallizing in aqueous solution, since this emission peak was larger, albeit at the same wavelength, when compound 3 was dissolved in an organic solvent, DMSO (data 
Table I. Estimated $\mathrm{IC}_{50}$ values (in $\mu \mathrm{M}$ ) for the compounds 1,2 and 3 in a small panel of mammalian cell lines.

\begin{tabular}{lcccccc}
\hline Compounds & HepG2 & Hepa1-6 & Caco-2 & HT-29 & HeLa & NIH3T3 \\
\hline 1 & $31.8 \pm 12.6^{\mathrm{b}}$ & $9.1 \pm 9.1$ & $>50$ & $30.5 \pm 10.0$ & $10.5 \pm 3.80$ \\
2 & $30.4 \pm 5.0$ & $5.9 \pm 2.5$ & $36.3 \pm 3.6$ & $20.7 \pm 3.8$ & $16.2 \pm 3.80$ & $13.5 \pm 11.6$ \\
3 & $39.6 \pm 7.1$ & $9.9 \pm 5.2$ & $>50$ & $14.0 \pm 5.7$ & $9.8 \pm 1.03$ & $12.5^{\mathrm{a}}$ \\
Cisplatin & 7.0 & 4.0 & 10.8 & 16.8 & 11.7 & 8.5 \\
\hline
\end{tabular}

${ }^{a}$ Based on single dose-response curve. ${ }^{b}$ Minimum of curve is $\geq 35 \%$ cell viability.

\section{Compound 3}
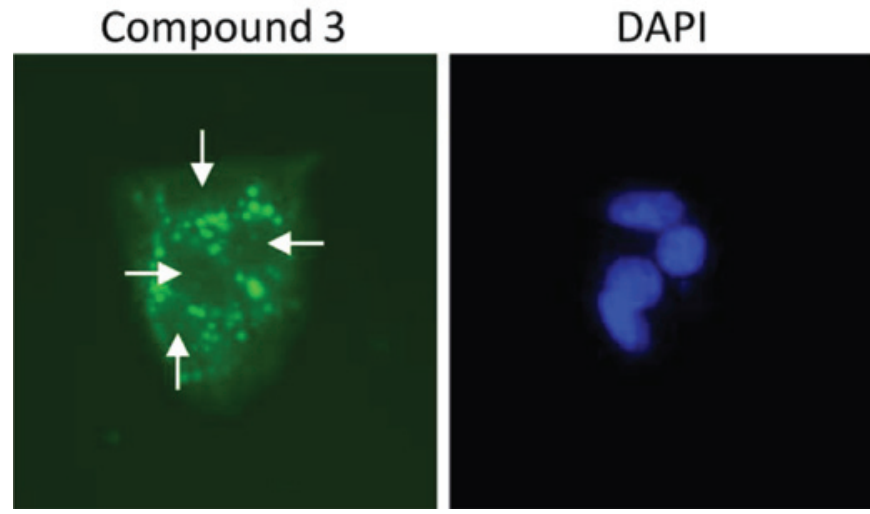

Figure 5. Subcellular localization of compound 3. HepG2 cells were treated with $50 \mu \mathrm{M}$ of compound 3 as described in Materials and methods. The compound accumulated in a punctate pattern (shown in green) outside of the nucleus (indicated by white arrows in the left panel and DAPI staining in the right panel).

not shown). Nonetheless, these data indicate that the addition of the long chains to either chrysene or pyrene caused a red-shift in spectral emission when compared to the PAHs (chrysene or pyrene).

Decreasing viability of multiple mammalian cell lines. Previous reports from our group and from other authors have shown that certain derivatives of PAHs, including pyrene and chrysene derivatives, reduce the viability of transformed cell lines $(1,20,34)$, and some of these PAH derivatives have been reported to reduce cell viability by induction of apoptosis $(34,35)$. Therefore, we tested the effects of compounds 1,2 and 3 on the viability of a small panel of human and mouse cell lines, including liver cancer cell lines (HepG2 and Hepa1-6), colon cancer cell lines (HT-29 and Caco-2), a cervical cancer cell line (HeLa) and NIH3T3 cells. Colon cancer and the HepG2 liver cancer cell lines were less susceptible to the effects of the three compounds when compared to other cell types; Caco-2 cells proved to be particularly resistant to the effects of these three compounds (Table I).

However, each compound was capable of reducing the viability of Hepa1-6, HeLa and NIH3T3 cells with an estimated $\mathrm{IC}_{50}$ value of $16 \mu \mathrm{M}$ or lower (Table I). Although compound 2 was generally slightly more cytotoxic than compound 1 , little difference in cytotoxicity was noted when comparing the pyrene (2) and chrysene (1) PAH-coupled compounds. Similarly, little difference in cytotoxicity was observed when comparing compounds 2 and 3 , suggesting that reduction of the carbamate group had little effect on the pyrene-coupled PAHs.

Since each of the three compounds was capable of reducing cell viability, at least of certain cancer and non-cancer cell lines, we also aimed to determine whether this reduction in cell viability occurred through the induction of apoptosis. We examined whether compounds 1, 2 and 3 treatment led to increased caspase 3/7 activity or increased DNA fragmentation (as measured by a TUNEL assay). We did not detect an increase in either of these apoptotic features in either HepG2 or Hepa1-6 cells in response to treatment with any of the three compounds analyzed (data not shown). Taken together, these data suggest that the ability of compounds 1,2 and 3 to reduce cell viability occurs through an apoptosis-independent mechanism.

A wide variety of planar ring systems are capable of intercalating with DNA, giving rise to many drugs that possess chemotherapeutic activity. In this context, three new polyaromatic derivatives containing polar side chains were systematically synthesized and investigated. The primary mode of action of these intercalators is believed to be their reversible binding to nuclear DNA, which causes inhibition of the replication process and, thus, cell death. As is well-known, cytotoxicity is not only dependent on the ability to interact with DNA. Instead, the drug must be capable of interacting with DNA to form a stable ternary DNA-intercalator-enzyme complex with a relatively long half-life in such a way that the enzymatic process cannot progress (11). Therefore, the low level of cytotoxicity observed for compounds 1-3 may be ascribed to an inability to access nuclear DNA or a low binding association (including a low affinity or highly transient interaction) to DNA.

Polyaromatic compounds 1-3 accumulate outside the cell nucleus. To determine whether the three novel polyaromatic compounds (i.e., compounds 1-3) were capable of accessing the nuclear DNA of cells, we examined their auto-fluorescent properties. HepG2 cells were treated with each compound (50 $\mu \mathrm{M})$. Cells were then fixed, stained with DAPI and observed using an epifluorescent microscope. Each of the three compounds was capable of being detected using a filter for enhanced green fluorescent protein, in accordance with their spectral emission properties (Figs. 2-4). We did not detect any of the three polyaromatic compounds in cell nuclei under these conditions, although compounds 1 and 2 formed crystals at these concentrations (data not shown). Interesetingly, compound 3 accumulated in a punctate pattern outside the cell nuclei (Fig. 5). This pattern is similar to a previous 
study (34) showing that a pyrene derivate accumulated in the cytosol of cells. These data suggest that the low level of cytotoxicity observed for these compounds is more likely due to their inability to access nuclear DNA in cells rather than a low binding affinity for DNA, although no studies have been performed to assess the DNA binding affinity of these compounds.

In conclusion, the present synthetic protocol allows for the preparation of three new polyaromatic compounds. Structure elucidation was carried out by various spectroscopic as well as elemental analyses. The addition of the long-chains to either chrysene or pyrene caused a red-shift in spectral emission when compared to the corresponding PAH itself. Furthermore, the cytotoxicity of the three novel polyaromatic compounds was evaluated in vitro in a panel of mammalian cell lines. Results showed that compound 2 exhibited better cytotoxicity compared to cisplatin against the HeLa cancer cell line, whereas compound 3, the pyrenyl ether, demonstrated better cytotoxicity against colon (HT-29) as well as cervical (HeLa) cancer cell lines. In summary, three new and promising anticancer PAH derivatives have been synthesized, and structural modification of these compounds is in progress. In addition, the method for synthesis of compounds 1-3 reported in this study may have applications in other areas of research.

\section{Acknowledgements}

The authors gratefully acknowledge the funding support from the National Cancer Institute (NIH/NCI-P20, Grant\# 5P20CA138022-02).

\section{References}

1. Banik BK and Becker FF: Synthesis, electrophilic substitution and structure-activity relationship studies of polycyclic aromatic compounds towards the development of anticancer agents. Curr Med Chem 8: 1513-1533, 2001.

2. Lerman LS: Structural c

onsiderations in interaction of DNA and acridines. J Mol Biol 3: $18-30,1961$.

3. Lerman LS: Structure of DNA-acridine complex. Proc Natl Acad Sci USA 49: 94-102, 1963.

4. Brana MF, Cacho M, Gradillas A, de Pascual-Teresa B and Ramos A: Intercalators as anticancer drugs. Curr Pharm Des 7: 1745-1780, 2001.

5. Martinez R and Chacon-Garcia L: The search of DNAintercalators as antitumoral drugs: what it worked and what did not work. Curr Med Chem 12: 127-151, 2005.

6. Malonne $\mathrm{H}$ and Atassi G: DNA topoisomerase targeting drugs: mechanisms of action and perspectives. Anticancer Drugs 8: 811-822, 1997.

7. Banik BK and Becker FF: Polycyclic aromatic compounds as anticancer agents: structure-activity relationships of chrysene and pyrene derivatives. Bioorg Med Chem 9: 593-605, 2001.

8. Wunz TP, Craven MT, Karol MD, Hill GC and Remers WA: DNA-binding by antitumor anthracene-derivatives. J Med Chem 33: 1549-1553, 1990.

9. Iyengar BS, Dorr RT, Alberts DS, Solyom AM, Krutzsch M and Remers WA: 1,4-disubstituted anthracene antitumor agents. J Med Chem 40: 3734-3738, 1997.

10. Dorr RT, Liddil JD, Sami SM, Remers W, Hersh EM and Alberts DS: Preclinical antitumor activity of the azonafide series of anthracene-based DNA intercalators. Anticancer Drugs 12: 213-220, 2001

11. Rescifina A, Chiacchio MA, Corsaro A, De Clercq E, Iannazzo D, Mastino A, Piperno A, Romeo G, Romeo R and Valveri V: Synthesis and biological activity of isoxazolidinyl polycyclic aromatic hydrocarbons: potential DNA intercalators. J Med Chem 49: 709-715, 2006.
12. Kamal A, Ramesh G, Srinivas O and Ramulu P: Synthesis and antitumour activity of pyrene-linked pyrrolo [2,1-c][1,4]benzodiazepine hybrids. Bioorg Med Chem Lett 14: 471-474, 2004.

13. Bair KW, Tuttle RL, Knick VC, Cory M and McKee DD (1-Pyrenylmethyl) amino alcohols, a new class of antitumor DNA intercalators - discovery and initial amine side-chain structure activity studies. J Med Chem 33: 2385-2393, 1990.

14. Bair KW, Andrews CW, Tuttle RL, Knick VC, Cory M and McKee DD: 2-[(arylmethyl)amino]-2-methyl-1,3-propanediol DNA intercalators - an examination of the effects of aromatic ring variation on antitumor-activity and DNA-binding. J Med Chem 34: 1983-1990, 1991.

15. Demeunynck M, Bailly $\mathrm{C}$ and Wilson WD: DNA and RNA Binders. Wiley-VCH, Weinheim, 2002.

16. De Vita VT, Hellman S and Rosenberg SA: Cancer: Principles and Practice of Oncology. 6th edition. Lippincott Williams and Wilkins, Philadelphia, PA, 2001.

17. Lown JW: Anthracycline and anthraquinone anticancer agents: current status and recent developments. Pharmacol Ther 60: 185-214, 1993.

18. Jemal A, Siegel R, Ward E, Murray T, Xu J and Thun MJ: Cancer statistics, 2007. CA Cancer J Clin 57: 43-66, 2007.

19. Banik BK, Basu MK and Becker FF: Novel disubstituted chrysene as a potent agent against colon cancer. Oncol Lett 1: 1033-1035, 2010.

20. Banik BK and Becker FF: Novel 6,12-disubstituted chrysene as potent anticancer agent: synthesis, in vitro and in vivo study. Eur J Med Chem 45: 4687-4691,2010.

21. Banik BK, Mukhopadhyay C and Becker FF: Synthesis and biological evaluation of novel dibenzofluorene derivatives as anticancer agents. Oncol Lett 1: 309-311, 2010.

22. Banik BK, Samajdar S and Becker FF: Asymmetric synthesis of anticancer $\beta$-lactams via Staudinger reaction. Mol Med Reports 3: 319-321, 2010.

23. Banik BK and Becker FF: Selective anticancer activity of $\beta$-lactams derived from polyaromatic compound. Mol Med Reports 3: 315-316, 2010.

24. Banik BK, Banik I and Becker FF: Asymmetric synthesis of anticancer $\beta$-lactams via Staudinger reaction: utilization of chiral ketene from carbohydrate. Eur J Med Chem 45: 846-848, 2010.

25. Banik BK, Banik I and Becker FF: Stereocontrolled synthesis of anticancer $\beta$-lactams via the Staudinger reaction. Biorg Med Chem 13: 3611-3622, 2005.

26. Banik BK, Becker FF and Banik I: Synthesis of anticancer 3-lactams: mechanism of action. Biorg Med Chem 12: 2523-2528, 2004.

27. Banik I, Becker FF and Banik BK: Stereoselective synthesis of $\beta$-lactams with polyaromatic imines: entry to new and novel anticancer agents. J Med Chem 46: 12-15, 2003.

28. Becker FF, Mukhopadhyay C, Hackfeld L, Banik I and Banik BK: Polycyclic aromatic compounds as anticancer agents: synthesis and biological evaluation of dibenzofluorene derivatives. Bioorg Med Chem 8: 2693-2699, 2000.

29. Becker FF and Banik BK: Polycyclic aromatic compounds as anticancer agents: synthesis and biological evaluation of some chrysene derivatives. Biorg Med Chem Lett 8: 2877-2880, 1998.

30. Vichai V and Kirtikara K: Sulforhodamine B colorimetric assay for cytotoxicity screening. Nat Protoc 1: 1112-1116, 2006.

31. Búcsiová L, Hrdlovič P and Chmela S: Spectral characteristics of fluorescence probes based on pyrene in solution and in polymer matrices. J Photochem Photobiol A Chem 143: 59-68, 2001.

32. Hrdlovič P and Chmela S: Spectral characteristics of probes based on ionic derivatives of pyrene in polar polymer matrices. J Photochem Photobiol A Chem 118: 137-142, 1998.

33. Spiro M, Vigny P and Hodgson RM: Fluorescence spectral studies on the metabolic activation of chrysene by hamster embryo cells. Carcinogenesis 3: 1491-1493, 1982.

34. Ohara K, Smietana M, Restouin A, Mollard S, Borg J, Collette Y and Vasseur J: Amine-guanidine switch: a promising approach to improve DNA binding and antiproliferative activities. J Med Chem 50: 6465-6475, 2007.

35. Landis-Piwowar KR, Chen D, Cui QC, Minic V, Becker FF, Banik BK and Dou QP: Apoptotic-inducing activity of novel polyaromatic compounds in human leukemic cells. Int J Mol Med 17: 931-935, 2006. 